\title{
Órfãos de pai e mãe: a necessidade antropológica da Direção Espiritual
}

\author{
Orientador: Joel Portella Amado \\ Mestrando: Cristiano Holtz Peixoto \\ Área de Concentração: Teologia Sistemático-Pastoral \\ Linha de Pesquisa: Religião e Modernidade
}

Um dos desafios que a Igreja enfrenta na atualidade é fazer com que a mensagem do Evangelho penetre nos corações humanos com profundidade, e isso se deve certamente à mentalidade hodierna, que exalta o individualismo. Existem diversas iniciativas pastorais que buscam atualizar sua linguagem para se tornarem capazes de falar ao coração do ser humano de hoje. Dentre essas, a Direção Espiritual, prática realizada no seio da Igreja desde os primeiros séculos, pode ser uma resposta coerente e mais compatível com a atualidade em virtude de sua própria dinâmica. O objetivo desta pesquisa é verificar em que medida a Direção Espiritual pode ser um auxílio para a pastoral contemporânea, estabelecendo-se inclusive como necessária do ponto de vista antropológico, uma vez que a maior necessidade do ser humano é a de ser acolhido como pessoa, mas também a de ser ajudado a abrir-se para Deus, para os outros e para o mundo.

Palavras-chave: Direção Espiritual. Antropologia Teológica. Conceito de Pessoa. 